\title{
From the Great Depression to Bretton Woods: Jacob Viner and International Monetary Stabilization (1930-1945) \\ Sebastiano Nerozzi*
}

\section{Abstract}

This paper examines Jacob Viner's contribution to the debate and the policy decision making concerning international monetary policy from the Great Depression to the Bretton Woods agreements. An outstanding member of the so called "early Chicago School of Political Economy", Viner was actively engaged in the debate over the causes and cures of the depression, emphasizing the important role international economic problems played in producing its onset and in reinforcing its duration. During the 1930's Viner was an outspoken supporter of international monetary cooperation, set up to secure exchange rates stability, which he regarded as a paramount factor in restoring business confidence and fostering recovery. As a close assistant to Secretary of the Treasury Henry Morgenthau, Jr. Viner was able to exert a positive influence on the administration's foreign economic policy, from the Gold Stabilization Act of 1934 to the Tripartite agreement of 1936. Though not directly involved in the Bretton Woods Conference, he played a role in preparing the ground for the establishment of multilateral agencies such as the IMF and the IBRD.

By means of his unpublished papers and other archival sources, as well as his writings, we will examine Viner's analysis of the Great Depression, his contribution to the debate over American foreign economic policy and his work as economic adviser from 1930 to 1945.

Keywords: Great Depression, Gold Stabilization Act, Tripartite Agreement, Bretton Woods, Jacob Viner.

JEL Classification: B31, E63, F55, F59, N12

\footnotetext{
*Catholic University of Milan, Institute of Economic Theory and Quantitative Methods. Via L. Necchi, 5, 20123, Milan. Correspondence may be addressed to sebastiano.nerozzi@tele2.it. I'm much indebted to Pier Francesco Asso and Eric Buyst for their useful comments on a previous version of this work. Two anonimous referees should also be credited for substantial improvement. Usual disclaimer applies.
} 


\section{Introduction}

"To understand the Great Depression", as has been contended, "is the holy grail of macroeconomics" (Bernanke 1995, p. 1). While many economists who had the experience of witnessing the Great Depression might not have agreed with this statement, many of them would have admitted that the set of events following the October 1929 stock-market crash puzzled them profoundly, shaking many of their previous beliefs. Moreover, the contemporary debate over the causes and the cures of the Great Depression laid the foundations for the laborious shaping of a new international economic order after World War II. In July 1944 forty-four countries accepted to give up part of their freedom in monetary matters and agreed to take part in the establishment of such multilateral institutions as the IMF and IBRD. To understand the reasons why they took these steps is to explore how politicians and economists perceived the disruption of international economic relationship between the two world wars and its impact on the onset and the propagation of the most dramatic depression the world had ever experienced. Despite a huge amount of historical reconstruction that has been provided on the workings of the international monetary system between the two World Wars, a systematic account of the contemporary debate over the same issues is still to be written.

In this paper we will focus on the contribution made in this context by the Canadian born economist Jacob Viner (1892-1970). From 1925 to 1945 Viner taught in Chicago and, along with Frank Knight, served as co-editor of the Journal of Political Economy. Viner's name is commonly associated with the "early" Chicago School of Political Economy. His original and subtle version of the quantity theory of money, and the applications he drew in the field of monetary and fiscal policy, have been regarded by Milton Friedman as a powerful source of inspiration and a cornerstone in the foundations of the so called "Chicago monetary tradition"1.

Viner was also part of another important monetary tradition, which stemmed from Harvard, and was particularly associated with the teaching of Frank W. Taussig. Viner had been one of Taussig's PhD students since 1917. Under his guidance, he realized one of the most important studies on the functioning of the classical gold standard. Analysing a wide set of banking and monetary statistics from 1900 to 1914 related to the Canadian Balance of International Indebtedness (Viner 1924), Viner provided an important contribution to the understanding of the specie flow mechanism,

\footnotetext{
${ }^{1}$ This claim is discussed at length in Nerozzi 2009b.
} 
with bank money and international capital flows. In the following years he continued devoting himself to the theory of international trade and to international monetary problems. His 1937 Studies in the Theory of International Trade has been widely regarded among the best historical introductions to the subject.

Viner was not only an appreciated scholar but also an economic adviser actively engaged in public service. After an initial experience in the U.S. Tariff commission from 1919 to 1922 he served as economic adviser almost continuously for two decades in the Roosevelt and Truman Administrations. From 1933 to 1945 he was involved, first as Special Assistant and then as Consultant, in the staff of the Secretary of the Treasury, Henry Morgenthau Jr.. In 1943 he was hired by the State Department as a consultant expert for economic affairs ${ }^{2}$.

In this paper we will focus on some of his activities as economic adviser in the international monetary field. Our analysis will be on a double level: the first level is mainly theoretical and aims at describing Viner's vision of the workings of the international monetary system, its impact on national economies during the depression and his evaluation of different exchange rates regime and possible institutional reforms. The second one is mainly concerned with the history of economic policy and aims at reconstructing Viner's contribution to the policy decision making during his service at the Treasury.

Each section is devoted to describing the outstanding events of American international monetary policy in which Viner was involved. First of all we analyse Viner's interpretation of the Great Depression and his appraisal of the reasons why the gold standard had failed to foster international stability, balance of payments equilibrium, or secure a high level of production and employment.

Then, Viner's activity as a close assistant to Secretary of the Treasury Henry Morgenthau J.r. is explored, paying particular attention to two episodes in which Viner exerted a positive influence on the Administration's foreign economic policy: the Gold Stabilization Act of 1934 and the Tripartite agreement of 1936.

Finally we examine Viner's contribution to the debate and the preparation of the Bretton Woods agreements. Though not directly involved in the Bretton Woods Conference, he played a manifold role in preparing the ground for the establishment of such multilateral agencies as the IMF and the IBRD.

\footnotetext{
2 On Viner's own recollections concerning his activity as economic adviser see Fiorito and Nerozzi (2008). Biographical accounts are provided by Samuelson (1972), Baumol and Seiler (1979), Rotwein (1983), Spiegel (1987). The most extensive intellectual profile is Bloomfield (1992). For his studies on the history of economic thought see Winch $(1981,1983)$ and Groenewegen (1994).
} 
Aside from Viner's writings, our analysis relies extensively upon his unpublished papers preserved in the Princeton University Library (JVP) and the Morgenthau Papers (MP) and Diaries (MD) in the Roosevelt Presidential Library.

\section{The Great Depression at an International Scale: from the Gold} Standard to Floating Exchange Rates.

Historical research has only recently provided an international setting to the Great Depression, exploring its onset, duration and termination in a wide set of countries and highlighting the channels by which powerful contractionary impulses were transmitted from country to country. In the 1960s and 1970s, the debate among economists was almost completely absorbed by the discussion of whether the "big crash" was the result either of monetary shocks, such as those highlighted by Milton Friedman and Anna Schwartz (1963) and Lester Chandler (1971), or of real forces such as an autonomous fall in consumption and investment spending (Tobin 1975; Temin 1976; Barber 1978; Rostow 1978; Gordon and Wilcox 1981; see also Romer 1993). On both sides of the debate the focus was mainly on the United States, with only passing references to what had happened in other countries or to international factors.

A new international and comparative approach to the Great Depression grew up in the 1980 s and rapidly outcast the old debate ${ }^{3}$. A sort of "new consensus" emerged, which Ben Bernanke summarized as follows.

Though in the end we may agree with Romer (1993) that shocks in the USA were a primary cause of both American and world depression, no account of the Great Depression would be complete without an explanation of the worldwide nature of the event, and of the channels through which deflationary forces spread among countries [...] Exhaustive analysis of the operation of the interwar gold standard has shown that much of the worldwide monetary contraction of the early 1930 s was not a passive response to declining output, but instead the largely unintended result of an interaction of poorly designed institutions, shortsighted policy-making and unfavorable political and economic preconditions (Bernanke 1995, pp. 1, 3)

While Bernanke's synthesis has not curbed a still vivid debate, yet it may be a useful starting point to compare the bearing of several decades of historical research on the Great Depression with the analysis provided by economists at the time.

Jacob Viner's analysis of the Great Depression and his policy proposals have been counted among the best examples of how mainstream economists were able to grasp

\footnotetext{
3 See for all: Choundri and Kochin 1980; Eichengreen 1984; Eichengreen and Sachs 1985; Hamilton 1988; Temin 1989; Bernanke and James 1991; Eichengreen 1992.
} 
much of the complexity and the scope of the 1929 crisis, without embracing any sort of oncoming theoretical revolution. Friedman recognized that especially in his 1932 lecture at the Harris Foundation Conference in Chicago, Viner exposed much of the arguments which he and Anna Schwartz were later to place at the center of their own explanation of the Great Depression. ${ }^{4}$ If we look at Viner's writings in the early 1930s we can better appreciate Friedman's claim. The Chicago economist anticipated Friedman and Schwartz's denounce of the Federal Reserve Board inability to formulate a consistent policy. Its weak and decentralized institutional structure prevented the Fed from acting effectively to stabilize business conditions at home and abroad (Viner 1931, p. 189; Viner 1932 [1951], p. 134). The Fed awkward policy was also due to the prevailing theoretical framework by which it designed its policies. Viner particularly blamed the persistent influence of the so called Commercial Loan Theory on the Fed which had impressed a strong pro-cyclical bias upon its operations ${ }^{5}$. When in 1927-1929 the Fed tried to curb speculation by restricting credit availability, its action deprived "legitimate" business of credit facilities and reduced the money in bank and cash circulation, provoking a general downturn in economic activity. It was the onset of the depression.

\begin{abstract}
Many Englishmen feel that the attempt of the Federal Reserve Board from 1927 to 1929 to check the growth of bank credit which was supporting security speculation in the United States was an unfavorable factor for England. It was impossible to distinguish between credit expansion for legitimate business purposes and expansion for speculation. The large demand for both types raised the money rate in the United States, and this drew money from England to this country and checked American foreign investments (Viner 1931, pp. 187-8).
\end{abstract}

As we shall see below, Viner did not deny that important real forces were at work in the second half of the 1920s, depressing world prices and preparing the ground for the depression. Yet he decidedly blamed on the Fed the onset and the deepening of the crisis: the dramatic prolongeddecline in aggregate demand had among its major causes the restrictive monetary policies enacted by the FED since 1929. Speaking in February 1933 Viner stated clearly:

It is often said that the federal government and the Federal Reserve system have practiced inflation during this depression and that no beneficial effects resulted from it. [...] On the contrary, the government and Federal Reserve bank operations have not nearly sufficed to countervail the contraction of credit on the part of the member banks and non-member banks. There has been no net inflation of bank credit since the end of 1929 . There has been instead a fairly

\footnotetext{
${ }^{4}$ Friedman 1972[2003], p. 156.

5 See Viner 1936, p. 117. Viner views were probably influenced by Lauchlin Currie's studies on the Fed policies (Currie 1931; 1933). In 1934 Viner called Currie at the Treasury in order to work out a banking reform. Moreover the two scholars agreed in supporting public expenditures and deficit spending. On Currie see Sandilands 1990, Laidler 1993, Laidler and Sandilands 2002.
} 
continuous and unprecedented great contraction of credit during the entire period. (Viner 1933a, pp. 21-2)

Even though in later years he was to change his opinion ${ }^{6}$, in 1931-1932 Viner held that monetary forces were driving real forces and not the other way round. Their impact on output and employment was mainly due to the diffused price and wage rigidities which prolonged - or even prevented - the adjustment of prices to the lower quantity of money and forestalled the restoration of full employment.

Yet Viner was well aware that the intensity and the scope of the depression could not be explained only by making resort to domestic factors. Contractionary forces had been working worldwide to weaken the whole system of international economic relations, driving most of the countries to fall in a deep depression.Viner's treatment of the causes of the depression and of the international effects of the Fed policies parallels with later reconstructions such as those provided by Temin (1989, p. 22) and Eichengreen (1992, pp. 217-220). First of all Viner defended the gold-exchange standard from the accusation to be itself responsible for the instability of international monetary relation and of the powerful deflationary forces at work all over the world. According to Viner, a fair appraisal of the gold-exchange standard should be based upon less mythical a view of the nature and the functioning of the classical gold standard. His view on the differences between the two monetary systems recalls the account provided by Temin (1989, pp. 8-9) and especially Eichengreen (1992, pp. 2966).The classical gold standard, like the gold-exchange standard, was not an automatic system; it was a "managed" international standard, whose functioning was due to the effective cooperation between the foremost central banks. This cooperation was mainly based upon a mix of common banking practices, informal consensus and personal relationships. ${ }^{7}$ Yet the new gold-exchange standard agreed upon at the 1922 Genoa Conference started its business in a highly unfavourable environment which hindered its proper functioning.

The growing rigidities in wages and prices operated to make changes in relative prices between countries a slower and less dependable adjustment factor. A contraction in foreign demand for national goods exerted its impact mainly by restraining output and employment: the traditional adjustment mechanism could exert its effect only indirectly, with great delay and with higher social costs (Viner 1932[1951], pp. 125-6).

Short term capital flows became very unstable and unpredictable, moving mainly in a destabilizing direction and strengthening the deflationary tendencies upon deficit

\footnotetext{
${ }^{6}$ On the evolution of Viner's views as the crisis deepened see Nerozzi 2007.

7 Viner 1932[1951], pp. 127, 129. See also Viner 1937, pp. 388-436.
} 
countries $^{8}$. Moreover reparations and war debts imposed an unreasonably heavy burden upon foreign trade and encouraged debtor countries to undertake beggar your neighbour policies in order to attain the trade surplus needed to repay their debts. Growing trade barriers and overproduction in foreign markets tended to depress world prices and to restrain international trade ${ }^{9}$.

The most important single manifestation of the dramatic disequilibrium in the international monetary system was the concentration of the $70 \%$ of world's monetary stock of gold in only two countries, namely, France and the United States. While the French accumulation of gold was due to a set of institutional factors ${ }^{10}$, in the United States, according to Viner, it should be blamed on the ominous monetary and commercial policies.

The trade surplus of the United States, resulting from the growing foreign demand for their mass production goods, and the increasing payments on account of the inter-allied debts were the basic driving forces in the inflow of gold reserves. Yet the restrictive monetary policy of the Federal Reserve had prevented the gold inflows to give rise to a corresponding increase in business activity and the price level.

\begin{abstract}
In the United States the failure of member banks, since 1922, to utilize freely their rediscount privileges with the Federal Reserve banks was one factor tending to prevent the increase in gold reserves from having its expected influence on the volume of business transactions and on the commodity price level. Much of the great increase in bank credit which did take place went into security and real estate speculation instead of into commerce; and while the price of securities and of real estate assuredly rose, the expectation of a still further rise and the increase in call money rates which resulted from the increased stock-market speculation, drew funds to this country instead of driving them out, as high commodity prices would have done (Viner 1932[1951], p. 131).
\end{abstract}

The tightening of credit conditions violated the "rules of the game", sterilizing the increase in the monetary base accruing from a growing trade surplus; its asymmetric impact on different financial activities led to a further destabilization of the adjustment mechanism, enhancing capital flows to the United States (Viner 1931, pp. 187-8).

At the same time the unwise protectionist policies enacted by the Government up to the Smoot-Hawley Tariff Act contributed to make more difficult for foreign countries to penetrate the American market and provide additional foreign reserves needed to finance imports and repay their debts. Even the sharp decrease, in the second half of the 1920's, of the flow of American long term investments abroad contributed to the

\footnotetext{
8 Viner 1932[1951], pp.132.

${ }^{9}$ Viner 1933 c, p. 109.

10 See Viner 1932[1951], pp. 131-132.
} 
accumulation of gold reserves. The consequences for many foreign countries in the gold standard were "inadequate gold reserves, a constant threat to the integrity of their currencies and a deflationary pressure on their prices in spite of embarrassingly rigid labor and other costs and inflexible internal and external public debt burdens" (Viner 1932[1951], p. 132).The collapse of the gold standard and the onset of the Great Depression were, according to Viner, nothing but the two faces of the same medal.

\begin{abstract}
An extraordinary collapse in world price levels, initiated by the termination of the new economic era in the United States and carried further downward by the competitive struggle of banks for liquidity and for protection of their reserves at whatever cost to the rest of the economic structure; a sudden cessation of the flow of new capital from creditor to debtor countries and a withdrawal of previously made short-term investments; a continuing burden of inflexible reparations, debt, and interest payments; a contagious plague of tariff increases, import prohibitions, and import quotas; a further decline in world price level and in volume of trade; then a succession of flights from the crown, the mark, the florin, and the pound sterling: and the gold standard, strained beyond the breaking point crashed (Viner 1932[1951], p. 133).
\end{abstract}

Viner did not ascribe to the gold-exchange standard the responsibility of the great depression. Given the complex and uncooperative way in which the gold standard had been managed, he admitted that many countries would have incurred less suffering with a well regulated paper currency ${ }^{11}$. The'golden fetters' had effectively prevented them from counteracting the deflationary forces under way and those who had freed themselves from them were likely to gain substantial advantages.

Yet, as for the United States, Viner's view was quite a different one: the United States should not itself go off the gold standard: its gold reserves were wide enough to allow a substantial expansion of the money supply without seriously threatening convertibility $^{12}$. A program of domestic expansion should be coupled with international monetary cooperation designed to strengthen the balance of payments of the countries still in the gold standard and to prevent new gold drains.

It is the interest of this country, as long as it remains on the gold standard, that as such as possible of the rest of the World also be on that standard. The restoration of the gold standard in those countries which have abandoned it would be hastened if it were cooperation to facilitate their return by such countries such as the United States and France, with surplus gold reserves. Such cooperation should take the form of legislative and administrative reductions in the legal minimum reserves, gold loans, and formal agreement for subsequent cooperation in the joint administration of the gold standard along international and mutually helpful line (Viner to Willits, February 1932, box 28, folder 22, JVP)

\footnotetext{
11 Viner 1932[1951], p. 133.

12 Viner 1932[1951], p. 139; Viner 1933a, p. 27; Viner 1933b, pp. 122-123.
} 
Viner's opinion about United States' ability to reflate the American economy without impairing their adherence to the gold standard revealed to be too optimistic. The open market purchases enacted by the Fed in the Summer of 1932 failed to attain an increase in the price level and were accompanied by growing capital outflows. An impressive chain of bank failures and financial panic gave rise to internal and external drain on gold reserves shrinking the quantity of bank money and causing a further slowdown in prices. Gold drains and capital outflows imperilled the US adherence to the gold standard.

In March 1933 Viner welcomed President Roosevelt's decision to declare a week of bank closure and to suspend convertibility. Once off the gold standard the United States could profit from the freedom acquired in order to enact bolder anti-depression policies. According to Viner this program should take the form of a deficit financed fiscal expansion and of banking reform. A bold program of public expenditures would have fostered the desired increase in prices, production and employment. At the same time international cooperation should be pursued in order to stabilize exchange rates and to restore international trade and overseas investments which were paramount to the recovery of the American economy. We will see in the next sections how this vision was to shape Viner's activity as public adviser in the following years.

\section{A Secret Agent for Dollar Stabilization (1933-1934)}

At the beginning of the 1930's Jacob Viner was an internationally renowned scholar and was often invited to lecture and teach abroad. In the summer of 1933 Viner moved to Geneva in order to spend one year at the prestigious International Institute of International Affairs founded by Michael Heilperin and directed by his own friend William Rappard. Yet, just a few days before sailing, Viner received a call from Henry Morgenthau Jr., head of the Farm Credit Administration, inviting the Chicago economist to meet him and President Roosevelt.

According to Viner's own recollections, Roosevelt asked him to engage a sort of special mission during his staying in Europe.

[Roosevelt] asked me if I would be willing to accept a post in the administration. I said no and I told him about the year in Europe. He said Morgenthau had told him about that and he was sorry, but he said, "I've a mission for you. Something I want you to do for me in Europe. I want you to send me a weekly letter, telling 
me what my administration looks like looked at from Europe. I want your view and also your view of what Europe sees it like." He told me to send it directly to him and to keep it confident (Jacob Viner 1953[2009], p. 91).

Viner accepted and sailed to Europe in July of 1933 . While still travelling he was informed of two important policy decisions taken by the Administration.

The first one was the passing of the National Industrial Recovery Administration Act, which he had strongly criticised during his meeting with the President; the second was the message launched by Roosevelt at the World Economic Conference, declaring the unwillingness of the American people to accept any international entanglement which could hinder their capacity to get out of the depression. The message fell as a bombshell on the World Economic Conference, which, loaded by divergences on a wide set of topics, finally collapsed.

These events upset him so greatly that he refused to fulfil the commitment he had taken with the President and continued travelling in Europe without writing any of the weekly letters the President had requested.

Yet in October of 1933 Viner received a call from Morgenthau who asked him to undertake an even more delicate and secret mission. Viner was to travel to London and Paris and collect information and opinions circulating in the most qualified circles regarding the American exchange rate policy ${ }^{13}$. At the time Roosevelt was trying to manipulate the gold value of the dollar, by means of the so called Gold Purchase Program. The Reconstruction Finance Corporation had been given the task of buying all the gold it was offered at the higher price established in international markets.

The Gold Purchase Program was based on the so called Warren-Pearson Doctrine which established a close correlation between the price of gold and that of basic agricultural products. An increase in the dollar price of gold would have induced a rise in the prices of basic agricultural products, thus providing relief to American farmers and fostering the recovery of the whole economy (Johnson 1939, pp. 10-16; Eichengreen 1992, pp. 338-341).

Since the gold purchases in the United States revealed to be ineffective in raising the dollar price of gold, Roosevelt, along with Morgenthau and Jesse Jones (head of the Reconstruction Finance Corporation) decided to start operating in the gold international markets of London and Paris. Viner's specific task was to provide additional information about European reactions to such a policy.

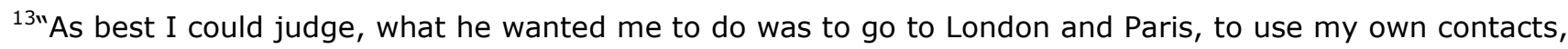
not going with official credentials of any sort, to talk to people, and find out what they thought about what was going on in the United States. He wanted me to go at once - even that night. I said, "That's impossible. The best I can do is to go tomorrow night", Viner 1953[2009], p. 94.
} 
From October 1933 to January 1934 Viner travelled from Geneva to both Paris and London (and the other way round) three or four times. Yet the climate he found was by no means friendly:

At the Bank of England [...] the feeling was one varying from frigid to heated hostility and irritation. I found difficulty in making a contact with anyone at the bank who was willing to speak at all frankly. The two officials of the bank whom I knew personally told me that they could not speak to me without prior permission from Mr. Norman, and warned me that if Norman knew of my presence in the Bank, whether my role was simply that of an inquiring American student or whether I came with the clearest of credentials from Washington, he would prohibit any member of the staff from speaking to me (Viner to Morgenthau, November 27, 1933, MP, Jacob Viner, I).

Viner was not very comfortable with this mission and did not like to be involved in a policy which he regarded, to say the least, as ill devised.

In Viner's opinion the Gold Purchase Program was erroneous in its economic foundations, ineffective in attaining its declared aims and dangerous for its consequences. In absence of a clear and openly declared objective, the result of this policy was not the depreciation of the dollar, but rather its erratic flotation in the exchange markets. The consequent destabilization of foreign exchange rates risked disrupting any prospect of international monetary cooperation, which was crucial to the recovery of the United States and of the world economy. According to Viner the most dangerous aspect of the dollar exchange instability was that it hindered and delayed the resumption of American investments not only abroad but also at home.

I do not believe Americans will freely invest their funds at home as long as the dollar is sinking on the exchange markets, and I do not believe recovery in American prices or economic activity is possible on a substantial scale until a resumption of internal investment on a large scale takes place. I believe that the exchange-value of the dollar has already been sufficiently depreciated to make possible a greater rise in American prices than is needed for full employment of American productive resources, and that expectation of further depreciation will operate as a check against recovery instead of a stimulus (Viner to Morgenthau, November 27, 1933, MP, Jacob Viner, I).

Viner pressed strongly for the termination of the Gold Purchase Program. He urged the Administration to declare a sudden stabilization of the external value of the dollar and to implement a set of policy measures, mainly public expenditures, capable of stimulating aggregate demand and eventually rising domestic prices to the desired level.

A few days before Christmas, Viner went to London and sent a telegram to Morgenthau suggesting the need to establish a Stabilization fund. This fund, equal to 
the proportions of the English one, should help achieving the stabilization of the dollar price of gold at $\$ 35$ per ounce, which was the level the Administration was aiming at. ${ }^{14}$

On January 15, Roosevelt addressed the Congress with a message that confirmed the Administration's willingness to stabilize the dollar price of gold at the level of $\$ 35.00$ per ounce, i.e., to $60 \%$ of its old parity which was fixed at $\$ 20.67$. The revaluation of the gold reserves in the vaults of the Treasury was used to build up a $\$ 2$ billion stabilization fund designed to defend the new parity from external pressures.

Two days later, Viner, sent a telegram stating that "the move that the Administration is now taking is in its main lines an excellent one".

Important changes were taking place within the Roosevelt Administration at the time. Henry Morgenthau Jr. was appointed Secretary of the Treasury in January and asked Viner to become his Special Assistant. In March 1934 Viner left his family in Geneva and sailed to the United States. He settled in Washington, and worked in the senior staff of the Secretary until December of the same year, when he returned to Chicago $^{15}$.

In the following ten years Viner continued to help at the Treasury, travelling regularly between Chicago and Washington, and providing suggestions and criticisms on issues of both domestic and international policy. We will see in the next section the contribution he made to important measures of international monetary stabilization.

\section{Negotiating the Tripartite Agreement (1934-1936)}

After the U.S. departure from the gold standard, the "free" world that was not dominated by totalitarian regimes could be divided roughly into three groups of countries: France and the other countries still operating on the gold standard, forming the so called "Gold Bloc"; Great Britain and the so called "Sterling Area", which included much of the Commonwealth; the United States with their most important trading partners, especially in the Western Hemisphere.

The Gold Stabilization Act of January 1934 provided a new anchor to world stability, establishing fixed exchange rates between the Gold Bloc and the United States. Yet the Gold Bloc itself was rapidly endangered by new pressures on its

\footnotetext{
${ }^{14}$ Viner to Morgenthau, December 22, 1933, MP, Jacob Viner, I.

15 On Viner's activity at the Treasury see Nerozzi 2007a; Fiorito and Nerozzi (2009).
} 
reserves: increasing capital flows directed to the United States, mainly due to the European political situation and Hitler's expansionism, were likely to force those currencies toward devaluation.

During the dollar flotation from the spring of 1933 to January 1934, the pound had been appreciating relatively to the dollar ( $\$ 5.15$ in November 1933) and depreciating toward the gold block's currencies. Yet, after the Gold Stabilization Act, it started depreciating again against the dollar, returning to the traditional exchange rate of $\$ 4.86$ at the beginning of 1935 . Economic recovery got under way in the United States, Great Britain and the countries that had tied their exchange rates to the pound or the dollar. American exporters profited from the dollar depreciation by penetrating in the gold bloc markets and displacing its producers from third countries (Eichengreen 1992, pp. 350-354). Trade deficits were widening in the gold standard countries and their reserves were under growing pressure. Deflation, unemployment and heavy political turmoil, along with financial distrust risked forcing them to abandon the gold standard (Oye 1985, pp.191).

Notwithstanding the advantages rapidly gained in foreign markets, the United States was still discussing the opportunity to enact a further devaluation. Economists like George Warren and Irving Fisher were pressing the Administration to reach a gold price of \$41-\$42 per ounce and to take bolder measure of monetary expansion.

As a result of the Gold Stabilization Act the Treasury had acquired a prominent role in monetary control and could influence the supply of money more effectively than the Federal Reserve Board itself, acting through several direct and indirect channels (Johnson 1939).

Starting in 1934 Viner strongly opposed Fisher's and Warren's influence within the Administration and raised an effective line of defence against their proposals. Moreover, heurged Morgenthau to start up negotiations to foster exchange rates stabilization. In the early spring of 1935, when the first contacts between France, England and the United States occurred, Viner wrote a memorandum to Morgenthau, explaining at length why and how monetary stabilization of exchange rates should be pursued.

Viner believed exchange stability was essential to the recovery of the American economy and of the world at large. In order to stimulate a rapid pace of productive investments, business confidence in the stability of the dollar needed to be strengthened. 
Capital has a tendency to be timid, and when sufficiently frightened flees abroad, or attempts to convert itself into hoards of the precious metals or into liquid securities convertible into cash at short notice. An unstabilized exchange tends to create mistrust as to the future currency, and will do so where there is not on the part of the investing public a habitual and unqualified confidence in the wisdom and financial conservatism of the currency authorities [...] Recovery will come only very slowly and very partially until capital funds, owned and borrowed again are freely invested in maintenance and replacement of old and construction of new factories, equipment, housing, etc.. Such investment of an adequate scale for prosperity cannot be expected until the fear of further depreciation of the dollar is removed, and the international stabilization by agreement is the only thing which in my opinion can quickly remove it (Viner 1935, pp. 1-2).

Viner held that both international trade and investments were affected by exchange rate risk. In order to make his powerful productive engines fulfil their potential, the American economy could not be satisfied with the present state of international trade, but should promote a higher level of its exports (Viner 1935, p. 3). The supporters of flexible exchange rates tended to deny that exchange rate instability could have such a negative impact on foreign investments and international trade: the technicalities of forward markets could compensate the losses due to unexpected exchange rates variations. Yet Viner believed that the range of currencies which had satisfactory forward markets were limited and could not handle large transactions. Moreover none of those markets could cover periods long enough to address the risks involved in long-term investments in sales promotion activities, which involved substantial investments and other commitments that dealt with foreign currencies.

A third argument was that, by assuring that the United States would have not engaged in currency depreciation, an international agreeement could induce other countries to behave the same way and not raise further trade barriers. An international agreement could be an anchor in international trade and stop or even reverse the ongoing tendency to beggar your neighbour's policies. In terms of modern game theory we could say that a flexible exchange rate could easily induce many countries to play a Nash-equilibrium game, while a commitment between the major countries could allow the attainment of a higher pay-off for all the players involved.

A fourth argument which Viner presented was that, in order to achieve a substantial rise in price levels, production and employment, a further depreciation was needed neither in the United States nor in the rest of the world (with the single exception of the Gold Bloc).

According to Viner, the shortage of foreign reserves needed to allow a steady flow of international trade was no longer a real problem: the world now had substantial 
gold reserves and other type of assets needed to raise its prices to a level consistent with full employment. Devaluations, institutional changes and increasing gold production had substantially increased the monetary potential of the existing reserves $^{16}$ :

The gold reserve basis of the world [is] sufficient to support for many years without gold reserve strain a price-level much higher than that of 1926-1929. Even with international stabilization the currency management problem will be soon one of preventing and excessive price rise rather than of promoting rise in prices or checking a fall (Viner 1935, p. 5).

Viner was probably too optimistic on the possibilities of an efficient use of the existing reserves, especially at an international level and for poorly endowed countries.Starting from this set of arguments, Viner's memorandum went on to analyse the concrete goals which the United States should aspire to when negotiating with other countries. The agreement should initially involve the United States, England, France, and "perhaps Japan", while the other nations would most probably be anchored to the currency of their major trading partner. Moreover the agreement should not commit the signers to return to the gold standard, but only to cooperate in stabilizing their exchange rates ${ }^{17}$.

A substantial devaluation of the French franc should be permitted in order to bring a halt to the pressures on French reserves and allow a balance of payments equilibriumconsistent with the lowering of the trade barriers France had raised in the last few years.

Yet, while the French government would have welcomed the opportunity of presenting the devaluation as part of a more general stabilization agreement designed to restore international equilibrium, the negotiations with the British were likely to be more difficult. They had experienced a hard and prolonged deflation and unemployment since 1925, due to the restoration of the English pound to its pre-war parity. After the departure from the gold standard they had rapidly reached a higher level of production and employment. Now they were not willing to tie their hands again. Yet, according to Viner, the perspective of a substantial lowering of trade barriers on the part of the Gold Bloc had a chance of convincing them to stabilize the Pound. Viner believed that the

\footnotetext{
${ }^{16}$ Viner 1935, pp. 4-5. Among the improvements in the managing of gold reserves Viner highlighted: "(1) The devaluations which have already occurred and will occur as part of an international stabilization agreement, (2) the abolition of circulating gold, (3) the flow of gold which has occurred from the hoards in India, the increase in gold production, which is likely to continue for some time [.... $]$, (4) the movement of privately hoarded gold into bank reserves when definitive stabilization occurs and (5) the lowering of central bank requirements which has occurred".

17 Viner 1935, p. 7.
} 
stabilisation of the Pound was acceptable at a level of $\$ 4.70$ or even $\$ 4.60$, which was below the level of $\$ 4.86$ established during the gold standard. Yet any attempt on the part of the British to bring the pound to $\$ 4.50$ o $\$ 4.40$ would have caused a monetary war with the Gold Bloc and a substantial further devaluation of the dollar.

Along these lines, Viner urged Morgenthau to take the proper steps necessary to start the negotiations with the British and the French. His recommendations converged with the views stemming from the Secretary's staff and by a memorandum favourable to stabilisation written by Alvin Hansen on behalf of the State Department ${ }^{18}$.

In May 1935 Harry Dexter White, a brilliant Harvard economist who had been called to the Treasury by Viner in the summer of 1934, was sent to Europe by Morgenthau to explore French and British attitudes toward an agreement. White's informal proposals, which closely resembled the one contained in Viner's memorandum, were welcomed by British Exchequer's officials (Clarke 1977, pp. 19-20; Boughton 2009, p. 12).

In the following months, the prospect for an agreement deteriorated: general political elections were near in France and the Prime Minister Laval refused to make any commitment to exchange rates stabilization. A new trip to England undertaken by White encountered a growing diffident environment towards the United States and France, which inspired to the British a policy of wait-and-see ${ }^{19}$.

The negotiations could start again in May 1936 after a new French government led by the socialist Leon Blum was established. The financial situation had grown difficult at the time and the instalment of the socialist government provoked additional capital flows that imperilled France's adherence to the gold standard.

Viner continued to play an influential part in supporting Morgenthau's commitment to achieve a stabilization agreement with France and England. The Secretary of the Treasury was not comfortable with problems of international monetary policy, got easily confused and needed to be advised on almost every detail (Clarke

\footnotetext{
18 Hansen's memorandum was sent to the Treasury on April 15 (Clarke 1977, p. 11). The arguments provided by Hansen were similar to Viner's, yet his proposal appeared to be less detailed and accurate in figuring out the proper level of exchange rates stabilization. Hansen supported a 20-25\% devaluation of the gold bloc and felt that a devaluation of the Pound ranging from 1/4.86 (which Viner believed to be too high to achieve equilibrium) and 1/4,50 (which Viner regarded as excessive) was acceptable. Hansen's memorandum upset President Roosevelt, who told Morgenthau that Hansen should be fired. This unhappy episode contributed in convincing Roosevelt that the negotiations should be concentrated in the Treasury with the State Department acting only on the side.

${ }^{19}$ At the time even Keynes was in favour of a de facto stabilization between the pound and the dollar which had to be based on an informal agreement between the two Treasuries without involving any legislative measure or official commitment (Eichengreen 1996, p. 135).
} 
1977, pp. 13-14) ${ }^{20}$. In August 1936, Morgenthau asked Viner his opinion on a quite unusual request the Treasury had received from Norway to sell to its Central Bank \$5 million in gold reserves. Viner and Morgenthau both believed that Norway was really siding with England, which was short of reserves at the time: Viner urged Morgentahu not to concede anything, fostering his pressures on the major countries to achieve a formal stabilization agreement, and not simply a de facto stabilization (MD 30, p. 167).

On September 4, 1936 the French government sent a draft of an agreement to the Treasury and Morgenthau called Viner to discuss the text of a possible reply ${ }^{21}$. After complex negotiations, the agreement was finally reached. On September 25, 1936 the governments of France, England and the United States sent the newspapers a message committing themselves to stabilizing their respective exchange rates and to combining their efforts to keep them stable. The French franc was devalued by $25 \%$ and the other countries of the Gold Bloc abandoned the gold standard. The English pound preserved its parity with the dollar at about $\$ 5$. That evening Morgenthau gathered his staff to celebrate the success. Viner told Morgenthau: "When they build your monument this will be high on the list of your battles".

Actually, Viner's and Morgenthau's hopes of a prolonged international stability were to be partially disappointed. Just a few months later, in June 1937, the franc was compelled to a new devaluation. Notwithstanding French inability to restore equilibrium and start up recovery, the period after the Tripartite Agreement was one of major stability in exchange rates and lower exchange risk premium on the foreign exchange markets for the world at large (Eichngreen 1992, pp. 380-382). Moreover the Tripartite Agreement proved that competitive devaluations and beggar your neighbour policies could be stopped by international agreement and that monetary cooperation between the governments was an effective and feasible objective. This lesson would not be cancelled by the dramatic events associated with the outbreak of World War II, but represented a positive landmark in the building up of a new world order.

\footnotetext{
${ }^{20}$ Aside from Viner and White, Morgenthau was helped by Herman Oliphant, Wayne C. Taylor, George Hass and Archie Lochhead during the negotiations (Blum 1959, pp. 160-161). Even Herbert Feis (economic adviser of the State Department and one of Viner's closest friends) was called in for advice in the final stages of the negotiations.

${ }^{21}$ In that occasion a sharp contrast developed between Viner and Morgenthau. While Viner thought that the French proposal should be discussed with the Fed, Morgenthau was not willing to involve Governor Eccles in the negotiations and recalled the President's view that the Governments should be the responsible for the agreement (Blum 1959, pp. 164-165).
} 


\section{Toward Bretton Woods}

Viner's contribution to the design of a new framework for international economic relationship after World War II was manifold. While he was not directly involved in the Bretton Woods agreements, he played an important part in their preparation and in the debate before its approbation on the part of the Congress.

Actually, Viner took part in the Administration's economic planning for the postwar world from its very beginning.Since October 1939, the Canadian-born economist had been involved in the War and Peace Study (WPS), a project set up by the Council on Foreign Relations in connection with the State Department ${ }^{22}$. The State Department received reports and recommendations from the WPS, which were delivered directly to the President and the Secretary of State $^{23}$. Given its personal connections and institutional framework, the WPS exerted a significant influence on the State Department, especially during the first three years of its activity, when an overall rethinking of the US national interests had to be worked out in order to guide short term decision making and long term strategies.

Moreover, a leading role within the WPS was assumed by the Economic and Financial Group (EFG), entrusted to the leadership of Viner and Alvin H. Hansen ${ }^{24}$. Between 1939 and 1945, the EFG sent 161 reports and recommendations to the State Department: they covered a wide set of topics, mainly related to the impact of the war on the American economy, the desirable aims for the American economy in the postwar economic order, and the political, economic and financial means needed to achieve them ${ }^{25}$. From the Atlantic Charter to the Mutual Aid Agreement and to the first AngloAmerican talks of September 1943 the WPS and EFG had a good deal of influence on the shaping of US foreign policy.

Despite their often divergent theoretical points of view, Hansen and Viner joined in championing a multilateral trade system and international exchange rate stability, as well as supporting the case for multilateral institutions to manage and develop the new international order.

\footnotetext{
${ }^{22}$ On the influence of the Council on Foreign Relations on Post war planning see Ikenberry 1993.

${ }^{23}$ Council on Foreign Relations, War and Peace Study Group, in George W. Ball papers, ca. 1933-94, Box 141, Mudd Library, Princeton University, pp. 9-10.

24 Both of them were former Presidents of the American Economic Association, respectively in 1939 and 1938. In addition to Viner and Hansen, the EFG counted other distinguished economists among its members: Lauchlin Currie (from January 1943), John H. Williams (only for a few months in 1940), Benjamin V. Cohen, Randolph Flanders (New York Fed), William Diebold Jr. (Junior researcher until 1943), Percy Bidwell, and Winfield Riefler. Many of them were already working with other agencies and Hansen had been adviser to the NBER and the Federal Reserve Board.

${ }^{25}$ George W. Ball, papers, Council on Foreign Relations, War and Peace Study Group: p. 10.
} 
Having discussed at length Viner's contribution to the EFG in a previous work ${ }^{26}$, we now focus on two important episodes, which, aside from the EFG, marked Viner's contribution to the preparation of the Bretton Woods agreement: Viner's assistance to White in redrafting an early version of his Plan in the winter of 1942 and Viner's correspondence with John Maynard Keynes in the spring and the summer of 1943.

In January 1942 Viner was called to Washington to serve again as Special Assistant to Morgenthau for a quarter. Morgenthau recommended that he worked in close connection with Harry D. White, helping him on every issue of financial and monetary policy.

On December 14, 1941, a few days after Pearl Harbour, Morgenthau had officially entrusted White to draft a plan for the establishment of an "Inter-Allied stabilization fund" which was later to become the basis for the Bretton Woods agreements.

White's ability in this field was proven ${ }^{27}$. After the Tripartite Agreement the Harvard economist had been appointed Director of the Stabilization Board, which was entrusted to manage the Exchange Stabilization Fund in order to keep the dollar exchange rate stable. In 1940 White had prepared a project for the establishment of an Inter-American Bank, which was designed to provide financial support to developmental projects in Latin America, help restructure sovereign debts and foster economic integration within the countries of the Western Hemisphere (Boughton 2009, pp. 1314). Viner was acquainted with this project before it was approved by the InterAmerican Financial and Economic Committee in February $1940^{28}$. The Inter-American Bank would have been a multilateral agency managed through a system of shares and votes in order to foster the participation of all the Countries in its financing and investment decisions. Yet the project failed to be approved by a sufficient number of Latin American countries and fell through (Rees 1973, pp. 103-104). According to Horsefield, White began developing a new project for a multilateral financial agency in the Summer of 1941, while negotiations for the Atlantic Charter were under way (Horsefield 1969, I, p. 12). The first draft of White's Plan suggested the establishment of two agencies: the United Nations Stabilization Fund and the Bank for Reconstruction of the United and Associated Nations, which would start their activity immediately after the end of the war. The former, endowed with a fund of $\$ 5$ billion in gold, national

\footnotetext{
26 Nerozzi 2009a.

27 On White's biography see Rees 1973 and Boughton 2004.

${ }^{28}$ White to Viner, January 11, 1940, box 28, folder 11, JVP; see also the draft preserved in box 49 , folder 4, JVP
} 
currencies and government bills, provided short term loans to support monetary gaps in the balance of payments of member countries; at the same time the Fund had the power to unilaterally change the parities of the various currencies, impose or abolish exchange controls, order appropriate adjustment policies upon credit as well as debtor countries ${ }^{29}$.

The Bank had even more ambitious goals: it would have the task of reducing world-wide business fluctuations, stabilizing raw material markets, and fostering the productivity and welfare conditions of lesser developed countries. It enjoyed practically the same powers as a central bank, with the ability to purchase and sell gold and national currencies, discount commercial papers and bills, issue banknotes and concede loans at very favourable rates. ${ }^{30}$

There is no documentary evidence showing the extent of Viner's contribution to the drafting of the White Plan. We only have some indirect indication that Viner knew about the existence of the plan and could have taken part in the revision of an early version of White's Plan. On January 10, Morgenthau pressured White to let Viner be involved in all the issues he was working on at the time (MD 492, p. 71).

We know that White was working hard to refine his Plan at the time. The first draft was substantially ready at the beginning of January $1942^{31}$ A second draft, with significant differences from the former, was produced in March and a third draft in April. We know that Viner served as Special Assistant from January 1 to March 31 . We can infer that he had the opportunity to contribute in the second and, perhaps, the third version of the plan. Viner wrote to Morgenthau on March 5 reminding him that at the end of that month he was returning to Chicago. He also announced that he intended to dedicate his work to the problems of Post-War order. Two of Viner's publications in 1942 concerned the monetary problems of the post war reconstruction (Viner 1942 a, b).

In May 1942 White's scheme was approved by Morgenthau and sent to an interdepartmental committee formed by representatives of many agencies. In Spring 1943 the White plan and the Keynes plan were published in the two countries.

In April 1943 Viner sent Keynes, forwarded by Dennis H. Robertson ${ }^{32}$, a first draft of a paper he was going to publish in the Yale Review, which compared the relative advantages of the British and the American Plans. Keynes wrote him a long

\footnotetext{
${ }^{29}$ Horsefield 1969, I, p. 74.

${ }^{30}$ Horsefield 1969, I, p. 75.

31 Gardner 1956 [1980], p. 74. The plan's first draft was dated December 30, 1941.

32 Box 16, folder 21, JVP. In 1943 Robertson was appointed economic adviser at the British embassy in Washington.
} 
letter, commenting on the paper point by point. A brief but very intense correspondence was exchanged from May to October 1943, when the final preparation of the first official talks between British and American delegation was under way. Keynes and Viner discussed the two plans in detail, finding a good deal of agreement on many issues. The letters, published in Keynes' Collected Writings (Keynes 194044[1980], pp. 320-35), are widely cited in the literature, but it is worth recalling some of their contents.

While appreciating many of the features of the Keynes plan (which was instead criticised by many American economists), Viner expressed his preference for the White plan. Granting to gold an inferior role than the White plan, the Keynes Plan was less acceptable to gold-producing or holding countries. Moreover Viner pointed out that, providing the fund with means of payment other than gold, the White plan was as able as the Keynes plan to enhance the elasticity of the world liquidity supply, preventing the risk of a new worldwide fall into deep depression. Inflation, in Viner's view, was the danger from which neither plan seemed to provide sufficient defence (Viner 1943, p. 210). Keynes did not deny the legitimacy of Viner's anxiety about inflation:

\begin{abstract}
Assuredly I share your concern about possible menace of inflation, or rather [...] the possibility of redundancy of gold. Experience shows that what happens is always the thing against which one has not made provision in advance. These currency schemes are providing against the danger of an insufficiency of international money. For my own part, I should not be at all surprised if, in fact, the actual danger which meets us turns out to be just the opposite, namely, an excess of international currency (Keynes to Viner, 9 June 1943: box 16, folder 21, JVP; Keynes [1940-1944], p. 324)
\end{abstract}

Viner's opposition to grant large drawing rights from US financial resources was not grounded on the fear of depletion of the reserves owned by the American banking system. Many countries had lost most of their productive resources during the war and needed large amounts of food, machinery and raw materials. The greater the provision of international reserves at their disposal, the greater the demand for goods which would fall on American industry. If this was coupled with industrial conversion to peace production, bottlenecks, scarcity of raw materials, and rapid inflation, instead of full employment, were likely to be the outcome. It was not worship of banking orthodoxy, which make American people to regard the Keynes plan as dangerous machinery:

The absence in the C[learing] $U$ [nion] of a rigid limit to the creditor obligations is of course very attractive per se to those who are debtor-minded but it is literally terrifying to those who anticipate being creditors. Whether inherently desirable or not, I think that limits to credit obligations will absolutely without question have to be conceded to make the new agency acceptable to all the essential countries 
(Viner to Keynes, 12 July 1943: box 16, folder 21, JVP; Keynes [1940-1944], pp. 327-8).

At this argument, already exposed in the paper, Keynes was ready to concede:

You here express the view that countries are not likely to accept an unlimited liability to be net creditors under a scheme. I should think it extremely likely that you are right about this. I have always felt that the difficulty is to find a satisfactory alternative (Keynes to Viner, 9 June 1943: box 16, folder 21, JVP; Keynes [19401944], pp. 322-3).

While clearly stating the reasons why the British plan could not be acceptable to American opinion, Viner admitted that a larger amount of resources and exchange flexibility should be permitted in the American plan, especially in the transition period.

This last point was particularly stressed by Viner: the transition period should be excluded from the activity of the new institution ${ }^{33}$. The heavy load of extraordinary imbalances in the early years after the end of the war, could not be effectively managed by the new institution, and certainly would have caused its collapse.

Here I come to the most important point I want to raise with you. I think that discussion of both plans has been befogged by failure to distinguish between the international financial problems of the period immediately following the cessation of hostilities and those of the long run more stable future. The expectation that the US will be alone or almost alone as a creditor is plausible for the first period. Over the long pull [...] I think the US is as likely to be short as to be long of foreign shortterm funds. But the difficulties re size of voting quotas, size of borrowing quotas, motives of the authors of the plans, etc. largely arise because the two plans are being interpreted primarily as plans to tide over the immediate post-war emergency period. [...] I think many apparent conflicts of opinion would disappear, and that it would be much easier to ascertain - and enlarge - the area of agreement (Viner to Keynes, 12 July 1943: box 16, folder 21, JVP: Keynes [1940-1944], pp. 330-1).

Viner was well aware of the huge financial aid the British needed to sustain their balance of payments in the transition period: only it had to be provided outside the Fund, through the traditional channels of inter-governmental loans. Viner declared on many occasions that this aid should be particularly generous (Viner 1943, p. 213) ${ }^{34}$.

\footnotetext{
33 On the economic problems of the transition period see Bordo (1993, pp. 37-48).

34 See Viner 1944[1951], pp. 245-246. On this point, Lionel Robbins, one of Viner's closest British friends, recalled that: 'During the war my own duties as a temporary U.K. official brought me into many Washington contacts; and often, where there were enlightened counsels and sensible policies, I detected traces of his [Viner's] influence. An incident in which he was involved deserves to be placed on permanent record. In early Summer of 1943, Harry White of the US Treasury Department organized an informal international gathering of delegates returning from the Food Conference in Hot Springs. The proceedings however were in the highest degree unfruitful. The US Treasury was not yet used to the organization of international meetings; and, apart from White's own exposition, delivered as it was from the bridge of a ship without a rudder in a stormy sea, there was little of great intellectual interest and much of political confusion. Towards the end, however, Jack, who had been asked in as an observer, was invited to comment. I do not remember the exact words in which he prefaced his candid expression of general disappointment with the perspective of the discussion. But I shall never forget the sentence in which he summed up his view of the irrelevance of the plans under discussion to the problems of the immediately
} 
At that time, Keynes, though convinced about the technical superiority of his plan, was becoming more malleable about the option of adopting other solutions, in order to achieve some sort of agreement (Skidelsky 2001, pp. 301-2). This exchange of letters with Viner probably added arguments to the case for putting aside his own plan and trying to improve the American one. Moreover Keynes was aware of Viner's reputation within the administration and its special relation with the Treasury ${ }^{35}$ : Viner's open mind or rigidity about certain critical points helped Keynes to guess what would have been the attitude of the American officials and to work out a better strategy for the negotiations ${ }^{36}$.

In September 1943, during the first Anglo American official talks, a compromise formula was agreed upon ${ }^{37}$. While expressing to Viner his satisfaction for this outcome, Keynes revealed his annoyance for the strong conditionality the Americans were imposing for the Fund's financial help, a point that Viner himself had stressed in his last letter ${ }^{38}$.

\begin{abstract}
Our view has been very strongly that if countries are to be given sufficient confidence they must be able to rely in all normal circumstances on drawing a substantial part of their quota without policing or facing unforeseen obstacles. [...] If the Clearing Union provisions were applied to the lower quotas now contemplated, we gravely doubt whether those concerned, particularly some of the smaller countries, would feel adequate confidence. [...] This, therefore, is a point about which, after further reflection, I cannot agree with you. No doubt it is a difficult issue (Keynes to Viner, 17 October 1943: box 16, folder 21, JVP: Keynes [1940-1944], p. 333).
\end{abstract}

The British could not deny the American request for stronger conditionality on the Fund's aid, but asked in turn a much higher degree of autonomy to revise exchange rates for reason of 'domestic political or social policy'39. Viner argued against this provision: it would have seriously injured the stabilization function of the Fund. It would have also exposed national monetary authority to political and social pressures for inflation and exchange devaluation.

\footnotetext{
post-war period. "I shall need" he said, "a bombproof shelter and you offer me an umbrella." Seldom can an economic prognosis have been more accurate.' (Robbins 1970, pp. 5-6).

${ }^{35}$ Keynes asked Viner for some further explanation of the Scarce Currency Clause: "Over here we find this feature of S[tabilization] F[und] rather obscure. Are you clear how it would work? Do you think that is a satisfactory way out?" Keynes to Viner, 9 June 1943 (box 16, folder 21, JVP).

${ }^{36}$ See Skidelsky 2001, pp. 300-320. On Viner's influence on Keynes in this concern, see ibid, pp. $303-5$.

37 See Horsefield 1969, I, pp. 58-77.

${ }^{38}$ Viner to Keynes, 12 July 1943: box 16, folder 21, JVP.

39 Actually the formula 'domestic and social policies' was inserted later in the negotiations and finally subscribed at Bretton Woods. But the shape of the compromise was in that direction (Skidelsky 2001, pp. 320).
} 
As to the criterion for permissible (or compulsory) changes in "normal" times, I don't think relative trends in "efficiency wages" would suffice, although they would be important. Exchange depreciations always have arbitrary differential effects as between foreign countries and internal economic groups, and, I think, are never a satisfactory means of adjustment of minor disequilibria. The wage criterion, moreover, accepts the business agent of the powerful trade unions as the ultimate and unlimited sovereign over monetary policy (Viner to Keynes, 12 July 1943: box 16, folder 21, JVP; Keynes [1940-1944], p. 329).

In the following months, prolonged discussions between (and within) the two sides of the Atlantic added to the "technicalities", in order to make the IMF acceptable to the respective public opinions ${ }^{40}$. The American refusal to concede adequate and automatic liquidity to debtor countries coupled with the British determination not to give up their freedom in pursuing full employment policies threatened the accomplishment of what could be regarded as the main content of the agreement: namely, international stabilization of exchange rates ${ }^{41}$.

Yet Viner was one of the few American economists to defend the outcome of the Bretton Woods Conference. According to many economists the "adjustable peg" regime established at Bretton Woods was an inferior substitute for both flexible exchange rates and the outright return to the gold standard. An intermediate approach was the one suggested by John $\mathrm{H}$. Williams, based upon the stabilization of the "key currencies" (a sort of renewed Tripartite Agreement) and the free flotation of the minor ones. The major advantage of his plan, according to Williams, was its simplicity: a simple agreement between the key countries avoided the complex institutional framework implied by the White and Keynes $\operatorname{Plan}^{42}$.

Viner's view was almost the opposite: he thought that multilateral agencies empowered to foster international economic cooperation were needed in a world in which national governments and central banks had proved to act in an entirely uncooperative and even nationalistic way. Moreover, the possibility of small countries to have their share in the financing and raise their voices in the process of decision making of the new agency was a strong political argument in their favour, since it could overcome the suspect that monetary or financial aid was provided in an imperialistic attitude from the rich countries to the poor ${ }^{43}$.

40 On the British discussions following the financial compromise of September 1943, see Pressnell (1986, 137-52), Skidelsky (2001, pp. 325-36). Concerning the American Debate, see Gardner (1956[1980], pp. 133-43).

${ }^{41}$ Viner 1944[1951], pp. 234-5.

42 On Williams views and proposals see Asso and Fiorito 2009.

43 Cfr. Nerozzi 2009a, pp. 36-37. 
On the whole, Viner insisted upon the need for an international financial agency as a crucial factor in attaining the type of postwar international economic order the United States were aiming at:

Without access to assured external credit facilities far beyond those available in the past, it is wishful thinking to expect most of the countries of the postwar world to be willing to accept serious stable exchange and free-exchange-market commitments [...]. Were it proper to regard the Monetary Fund negotiations as negotiations between the United States on the one hand and the rest of the United Nations on the other hand, the bargain tentatively reached is obviously one under which the other countries make commitments with respect to exchange stability and freedom of exchange markets from restrictive control while we in turn pledge financial aid to countries needing it to carry out these commitments (Viner 1944[1951], p. 238).

\section{Conclusions}

The extensive analysis of Jacob Viner's writings and unpublished papers may serve to highlight the outstanding features of his contribution to the design of American international monetary policies from 1930 to 1945.

First of all we can appreciate the accuracy and the ample scope of Viner's analysis of the Great Depression. As a moderate supporter of the gold-exchange standard, he did not blame the great depression on it, but pointed out the difficult problems which had forestalled its functioning after World War I, acting as a powerful deflationary twist on the major countries adhering to the system. While proposing important institutional changes in order to improve the functioning of the gold standard, the Canadian-born economist regarded exchange rate stability as the crucial factor in allowing a revival in international trade, in fostering overseas investments and in realizing a full recovery of the American economy and the world at large.

This vision decidedly inspired Viner's activity as economic adviser. During his prolonged service at the Treasury, he gave priority to the goal of exchange rate stability. We can state that, under this respect, his vision exerted a good deal of influence on the Administration, especially in relation to the Gold Stabilization Act and the Tripartite Agreement.

Although not directly involved in the negotiations related to the Bretton Woods agreement, he played a part backstage, probably helping White refine an early version of his Plan, publicly discussing the relative merits of the Keynes and White plans and 
entertaining an intense correspondence with Keynes at a crucial stage of the negotiations.

The outcome of the conference was quite disappointing to him: he complained especially of the low degree of exchange stability it seemed to warrant and of the inability of the Fund and the Bank to assure a steady flow of long-term international investments. Yet he preferred to side publicly in favour of the plans since he thought that the establishment of such multilateral agencies as the IMF and the IBRD was needed to foster international cooperation. Without a cooperative effort to manage the international and financial monetary system, it would be impossible to secure a fair adjustment of balance of payments and prevent exchange rates instability.

Though Viner's education was solidly grounded on the classical and neoclassical theory, the experience of the Great Depression had weakened his faith in the selfadjusting properties of the economic system. Governments and Central Banks had a crucial responsibility to enact proper fiscal and monetary policies and to cooperate in the proper management of the international monetary system. Yet his commitment to free trade remained unshaken. Only fair trade practices and the free flow of overseas investments could finally restore those levels of diffused social welfare which were needed to secure peaceful international relations. The Bretton Woods Agreements were, according to him, only a first step in the building up of a fair and peaceful system of international economic relations. Perhaps we need to admit that most of those hopes are still awaiting their day. 


\section{References}

Asso, P.F. and Fiorito L., 2009, A Scholar in Action in Interwar America: John H. Williams on Trade Theory and Bretton Woods, in R. Leeson, ed., American Power and Policy, III, Basingstoke, Palgrave-Macmillan, 2009, pp. 180-242.

Barber, C.L., 1978, On the Origins of the Great Depression, Southern Economic Journal, 44, pp. 432-56.

Baumol W.J and E. V. Seiler, 1979, Viner, Jacob in International Encyclopedia of the Social Sciences: Biographical Supplement, D.L. Sills, ed., New York, Free Press, 18, pp. 783-787.

Bloomfield, A., 1992, On the Centenary of Jacob Viner's Birth. A Retrospective View of the Man and His Work, Journal of Economic Literature, XXX, 1992, 4, pp. 2052-2085.

Blum, J.M., 1959, From the Morgenthau Diaries: Years of Crisis, 1934-1938, Boston, Houghton Mifflin.

Bernanke, B. S., and James, H., 1991, The Gold Standard, Deflation and Financial Crisis in the Great Depression: an International Comparison, in R. G. Hubbard, ed., Financial Markets and Financial Crises, Chicago, Chicago University Press.

Bernanke, B. S., 1995, The Macroeconomics of the Great Depression: a Comparative Approach, Journal of Money, Credit and Banking, vol. 27, n.1, pp. 1-28.

Bordo, M.D., 1993, The Bretton Woods International Monetary System: A Historical Overview, in Bordo, M.D. and B. Eichengreen, 1993, eds., A Retrospective on the Bretton Woods System: Lessons For International Monetary Reform, Chicago, London, The University of Chicago Press, pp. 3-107.

Boughton, J.M., 2004, New Light on Harry Dexter White, Journal of the History of Economic Thought, 26, June, pp. 179-95.

Boughton 2009, America in the Shadows: Harry Dexter White and the Design of the International Monetary Fund, in R. Leeson, ed., American Power and Policy, III, Basingstoke, Palgrave-Macmillan, pp. 6-23.

Chandler, L.V., 1971, America's Greatest Depression, 1929-1941, New York, Harper and Row.

Choundry, E. U. and L. A. Kochin, 1980, The Exchange Rate and the International Transmission of Business Cycle Disturbances: Some Evidence From The Great Depression, Journal of Money, Credit and Banking, 12, pp. 565-74.

Clarke, S.V.O., 1977, Exchange-rate stabilization in Mid-1930s: Negotiating the Tripartite agreement, Princeton Studies in International Finance, n. 41, Princeton N.J., Princeton University Press.

Currie, L.B., 1931(2004), Bank assets and Banking theory, Unpublished PhD Thesis, published in Journal of Economic Studies, 2004, 31, 3-4.

Currie, L.B., 1933, Member Bank Reserves and Bank Debits, Quarterly Journal of Economics, 46, February, pp. 509-525.

Eichengreen, B., 1984, Central Bank Cooperation and Exchange Rate Commitments: The Classical and Interwar Gold Standard, Explorations in Economic History, 21, pp. 64-87.

Eichengreen, B., 1992, Golden Fetters: the Gold Standard and the Great Depression, 1919-1939, New York, Oxford University Press.

Eichengreen, B., 1996, Globalizing Capital: a History of the International Monetary 
System, Princeton, N.J., Princeton University Press.

Eichengreen, B. and J. Sachs, 1985, Exchange Rates and economic recovery in the 1930s, Journal of Economic History, 45, pp. 925-46.

Friedman M., 1972(2003). Comments on the Critics: Patinkin, Reprinted in R. Leeson, ed., Keynes, Chicago and Friedman, I, London-Brookfield, Pickering and Chatto, pp. 14566.

Friedman M. and Schwartz A., 1963, A Monetary History of the United States, Princeton, NJ, Princeton University Press.

Gardner, R.N., 1956(1980), Sterling-Dollar Diplomacy in Current Perspective, The Origins and The Prospects of Our International Economic Order, New expanded Edition, New York, Columbia University Press.

Groenewegen, P., 1994, Jacob Viner and the History of Economic Thought, Contribution to Political Economy, 1994, 3, pp. 69-86.

Gordon, R.J. and J.A. Wilcox, 1981, Monetarist Interpretations of the Great Depression: an Evaluation and Critique, in Karl Brunner, ed., The Great Depression Revisited, Martinus Nijhoff, L'Aia, pp. 49-107.

Hamilton, J.D., 1988, The Role of the International Gold Standard in Propagating the Great Depression, Contemporary Policy Issues, 6, pp. 67-89.

Horsefield, J.K., 1969, ed., The International Monetary Fund 1945-1965: Twenty Years of International Monetary Cooperation, vol. 2, Washington, D.C., International Monetary Fund.

Ikenberry, G.J, The Political Origins of Bretton Woods, in Bordo, M.D. and B. Eichengreen, 1993, eds., A Retrospective on the Bretton Woods System: Lessons For International Monetary Reform, Chicago, London, The University of Chicago Press, pp. 155-98.

Laidler, D., 1993, Hawtrey, Harvard and the Origins of the Chicago Tradition, Journal of Political Economy, 101, December, pp. 1068 -1103.

Laidler, D. and Sandilands, R. J., 2002, An Early Harvard Memorandum on AntiDepression Policies: An Introductory Note, History of Political Economy, Volume 34, Number 3, Fall, pp. 515-532.

Johnson, G.G., 1939, The Treasury and Monetary Policy (1933-1938), Cambridge, MA, Harvard University Press.

Keynes, J.M., 1940-44 (1980), Activities 1940-44; Shaping the Post-War World, the Clearing Union, Collected Writings, XXV, [D. Moggridge, ed.], London, Macmillan, Cambridge University Press.

Nerozzi, S., 2007a, Between Harvard and Chicago: Jacob Viner and New Deal Banking Reforms, 1933-1935. Storia del Pensiero Economico, 2 December, pp. 29-66.

Nerozzi, S., 2009a, Building up a multilateral strategy for the United States: Jacob Viner, Alvin Hansen and the Council on Foreign Relations, 1939-1945, in Robert Leeson, ed., American Power and Policy, III, Basingstoke, Palgrave-Macmillan, pp. 24-68.

Nerozzi S., 2009b, Jacob Viner and the Chicago Monetary Tradition, History of Political Economy, vol. 41, 3, Fall 2009, pp. 575-604.

Oye, K.A., 1985, The Sterling-Dollar-Franc Triangle: Monetary Diplomacy 1929-1937, World Politics, Vol. 38, No. 1, October, pp. 173-199.

Pressnell, L.S., 1986, External Economic Policy since the war, Vol. I, The Post-War 
Financial Settlement, London, Her Majesty's Stationery Office.

Rees, D., 1973, Harry Dexter White, A Study in Paradox, New York, Coward, McCann \& Geoghegan.

Robbins, L., 1970, Jacob Viner (1892-1970). A Tribute, Princeton N.J.: Princeton University Press.

Romer, C., 1993, The Nation in Depression, The Journal of Economic perspectives, 7, Spring, pp. 19-39.

Rostow, W.W., 1978, The World Economy: Theory and Prospect, Macmillan, London.

Rotwein E., 1983, Jacob Viner and the Chicago Tradition, History of Political Economy, Summer 983, XV, 2, pp. 265-280.

Samuelson, P., 1972, Jacob Viner (1892-1970), Journal of Political Economy, Jan.-Feb. 1972; LXXX, 1, pp. 5-11.

Sandilands, R.J., 1990, The Life and Political Economy of Lauchlin Currie, Duke University Press, Durham, NC.

Spiegel, H. W., 1987, Viner, Jacob, The New Palgrave Dictionary of Economics, vol. 4, Macmillan, London; New York, Stockton; Tokio, Maruzen.

Skidelsky R., 2001, John Maynard Keynes, Fighting for Britain (1937-1946), New York \& London, Viking.

Temin, P., 1976, Did Monetary Forces Cause the Great Depression? New York, W.W. Norton.

Temin, P., 1989, Lessons from the Great Depression: The Lionel Robbins Lectures for 1989, Cambridge MA, MIT Press.

Tobin, J., 1975, Keynesian Models of Recession and Depression, American Economic Review papers and Proceedings, May, 65, pp. 195-202.

Viner, J., 1924, Canada's Balance of International Indebtedness: 1900-1913. An Inductive Study in the Theory of International Trade, Cambridge, MA, Harvard University Press.

Viner, J., 1931, Problems of International Commercial and Financial Policy . In Report of the round tables and general conferences at the eleventh session, edited by in A. $\mathrm{H}$. Buffington, Institute of politics, Williamstown, MA, pp. 165-93.

Viner, J., 1932(1951), International Aspects of the Gold Standard. Reprinted in Viner, J., 1951, pp. 123-40.

Viner, J., 1933a, Balanced Deflation, Inflation or More Depression, Day and Hour series of the University of Minnesota 2, Minneapolis, University of Minnesota press.

Viner, J., 1933b, Inflation as a Possible Remedy for the Depression, Proceedings of the Institute of Public Affairs, University of Georgia, pp. 120-35.

Viner, J., 1933c, Tariff Reduction by International Agreement, Proceedings of the Institute of Public Affairs, Athens, Ga., University of Georgia, pp. 108-119.

Viner, J., 1935, Memorandum on International Monetary Stabilization, unpublished, Viner Jacob, File I, MP, FDRL.

Viner, J., 1936, Recent Legislation and the Banking situation, American Economic Review, Supplement. 26. March, pp. 106-19.

Viner, J., 1937. Studies in the Theory of International Trade. New York - London, Harper 
\& Brothers.

Viner, J., 1942a, The International Economic Organization of the Future, in Toward International Organization, Oberlin College Lectures, New York, Harper \& Brothers, pp. 110-37.

Viner, J., 1942b, Objectives of Post-War International Economic Reconstruction, in Mc Kee, W. - L. Wiesen L., eds., American Economic Objectives, New Wilmington, Pa, Economic and Business Foundation, pp. 161-85.

Viner, J., 1943(1951), Two Plans for International Monetary Stabilization, The Yale Review, Vol. 33, Autumn 1943, 77-107; republished in Viner J., 1951, pp. 192-215.

Viner, J., 1944(1951), The Case for the Bretton Woods Agreement, in Shields, M., 1944), ed., International Financial Stabilization. A Symposium, Irving Trust Company, NY, republished in Id., 1951, pp. 232-46.

Viner, J., 1951, International Economics, Glencoe, IL, Free Press.

Viner, J., 1953(2009), Jacob Viner's Reminiscences from the New Deal. Edited with an introduction by Luca Fiorito and Sebastiano Nerozzi, in Research in the History of Economic Thought and Methodology, 27A, June 2009, pp. 75-136.

Winch D., 1981, Jacob Viner, The American Scholar, 50, 4, pp. 519-25.

Winch D., 1983, Jacob Viner as Intellectual Historian, Research in the History of Economic Thought and Methodology, vol. 1, pp. 1-17.

\section{Archival Sources:}

JVP: Jacob Viner Papers, Seeley G. Mudd Manuscript and Rare Books Library, Princeton, NJ

MP: Morgenthau Papers, Franklin D. Roosevelt Presidential Library and Museum, Hyde Park, NY.

MD: Morgenthau Diaries, Franklin D. Roosevelt Presidential Library and Museum, Hyde Park, NY. 